\title{
Transient Gene Expression of $\beta$-glucuronidase in Citrus Thin Epicotyl Transversal Sections Using Particle Bombardment
}

\author{
João C. Bespalhok Filho, Adilson K. Kobayashi, Luiz F. P. Pereira, Rafaelo M. Galvão and \\ Luiz G. E. Vieira* \\ Laboratório de Biotecnologia Vegetal; Área de Melhoramento e Genética; Instituto Agronômico do Paraná \\ (IAPAR); C. P. 481; 86001-970; Londrina - PR - Brazil
}

\begin{abstract}
Studies were carried out to optimize the conditions for transient gene expression through particle bombardment on Carrizo citrange (Citrus sinensis x Poncirus trifoliata) thin epicotyl sections. The best conditions for transient GUS expression were: M-25 tungsten particles, $1550 \mathrm{psi}$ helium pressure, $9 \mathrm{~cm}$ distance between specimen and DNA/particle holder and culture of explants in a high osmolarity medium $(0.2 \mathrm{M}$ mannitol $+0.2 \mathrm{M}$ sorbitol) $4 \mathrm{~h}$ prior and $20 \mathrm{~h}$ after bombardment. Under these conditions, an average of 102 blue spots per bombardment (20 explants/plate) were achieved. This protocol is currently being used for transformation of Carrizo citrange and sweet orange (Citrus sinensis).
\end{abstract}

Key words: Transformation, uidA expression, biolistics, transgenic citrus

\section{INTRODUCTION}

Several aspects can limit citrus breeding. Most of citrus species are apomictic and their seeds produce nucellar embryos that limit the development of zygotic embryos. They also have high heterozygosity that produces a great segregation of genetic characters in the progeny. As a perennial species, they have a long juvenile period needing 5-8 years to start flowering and fruiting (Gmitter et al., 1992, Peña and Navarro, 1999). Genetic transformation is an alternative to reduce the time needed to produce citrus genotypes with new traits.

Transgenic citrus plants have been obtained by direct DNA transfer into protoplasts (Vardi et al., 1990), co-cultivation of internode or epicotyl segments with Agrobacterium (Moore et al., 1992, Peña et al., 1995a, Gutiérrez et al., 1997) and particle bombardment of nucellar embryogenic cell suspensions (Yao et al., 1996). At present, the most widely used method of gene transfer in citrus is the Agrobacterium-mediated transformation of epicotyl segments with $1 \mathrm{~cm}$ of length. Using this system, transgenic plants of $C$. sinensis (Peña et al., 1995a, Bond and Roose, 1998), C. aurantifolia (Gutiérrez et al., 1997), C. aurantium (Peña et al., 1997), C. paradisi (Luth and Moore, 1999), C. sinensis x Poncirus trifoliata (Moore et al., 1992; Peña et al., 1995b) and $P$. trifoliata (Kaneyoshi et al., 1994) have been obtained. However, one limitation of this system is the high number of non-transformed (escapes) and chimeric plants. One possible reason for this is that the large size of

\footnotetext{
*Author for correspondence
} 
the initial explants may allow the growth of nontransformed shoots during the selection phase due to the protective effect of the surrounding transformed cells and/or a gradient concentration of selective agent on the explant.

In a previous paper we described a protocol for efficient regeneration of sweet orange (cvs. Pera, Valencia and Folha Murcha) from thin epicotyl sections and discussed the possibility of using this type of explants in direct transformation using particle bombardment (Bespalhok et al., 2001). The present study was designed to optimize transient gene expression on thin epicotyl explants of Carrizo citrange and sweet orange cv. Pera using particle bombardment.

\section{MATERIALS AND METHODS}

Seeds of Carrizo citrange (Citrus sinensis (L.) Osbeck $x$ Poncirus trifoliata (L.) Raf.) and sweet orange (Citrus sinensis (L.) Osbeck) cv. Pera were peeled removing both seed coats, surface disinfected with $2.5 \%(\mathrm{v} / \mathrm{v})$ sodium hypoclorite solution for $10 \mathrm{~min}$ and rinsed three times with sterile distilled water. Seeds were sown individually in polypropylene-capped $150 \times 25$ $\mathrm{mm}$ test tubes containing $25 \mathrm{~mL}$ of culture medium consisting of MS salt solution (Murashige and Skoog, 1962) supplemented with $30 \mathrm{~g} \mathrm{~L}^{-1}$ sucrose and solidified with $9 \mathrm{~g} \mathrm{~L}^{-1}$ Agar. The $\mathrm{pH}$ was adjusted to 5.7 before autoclaving. The cultures were maintained in darkness at $28 \pm 1^{\circ} \mathrm{C}$. First, explants of Carrizo citrange were used for optimization experiments. The best conditions determined for Carrizo (see results) were subsequently used for bombardment of sweet orange cv. Pera.

Epicotyls from 3 to 5 -week-old seedlings were removed, hand cut transversally into thin sections (1-2 mm), inoculated with the basal end of the explant in contact with culture medium supplemented with $5 \mu \mathrm{M}$ benzyladenine (BA) and cultured in the dark at $28 \pm 1^{\circ} \mathrm{C}$. Approximately 100 thin epicotyl explants were inoculated per Petri dish $(9 \times 1.5 \mathrm{~cm})$. After one week of culture, explants with callus formation were selected under

a dissecting microscope and used for bombardment experiments. Explants were distributed randomly across treatments. For each bombardment, twenty explants were placed in the center of a $6 \mathrm{~cm}$ Petri dish.
Plasmid pE2113-GUS (Mitsuhara et al., 1996) was used for bombardment experiments. This plasmid contains the uidA gene under a constitutive high expression promoter consisting of the CaMV 35S promoter, 2 repeats of the $5^{\prime}$ enhancer sequence of CaMV 35S promoter and an $\Omega$ sequence from the tobacco mosaic virus (TMV). The plasmid also contains the selectable marker gene npt II under the control of the NOS promoter.

The microprojectile suspension was prepared as described by Sanford et al. (1993) using $25 \mu \mathrm{L}$ particles suspension $\left(60 \mathrm{mg} \mathrm{ml}^{-1}\right), 2.5 \mu \mathrm{L} \mathrm{pE2113-}$ GUS (0.5 mg mL ${ }^{-1}$ in TE buffer), $25 \mu \mathrm{L} \mathrm{CaCl}_{2}$ (2.5 $\mathrm{M})$ and $10 \mu \mathrm{L}$ spermidine $(0.1 \mathrm{M})$. Six $\mu \mathrm{L}$ of the microprojectile suspension were pipetted onto each macrocarrier and dried in a laminar flow hood. Three types of particles were tested: tungsten M-17 (BioRad, $1.1 \mu \mathrm{m}$ ), tungsten M-25 (BioRad, $\sim 1.7 \mu \mathrm{m}$ ) and gold (Aldrich, 1.5-3.0 $\mu \mathrm{m})$. The PDS-1000/He device was used with a vacuum of $27 " \mathrm{Hg}, 10 \mathrm{~mm}$ distance from rupture disk to macrocarrier and $10 \mathrm{~mm}$ macrocarrier flight distance. Two rupture disk pressures (1100 and $1550 \mathrm{psi})$ and two microprojectile travel distances $(60 \mathrm{~mm}$ or $90 \mathrm{~mm})$ were evaluated. The effect of pre- and post-bombardment treatments (4 and $20 \mathrm{~h}$, respectively) with osmoticum $(0.2 \mathrm{M}$ mannitol $+0.2 \mathrm{M}$ sorbitol) was tested.

Following bombardment, plates were sealed and cultured for $24 \mathrm{~h}$ at $28 \pm 1^{\circ} \mathrm{C}$ in the dark. GUS activity was assayed histochemically counting the blue spots produced, according to the procedure of Jefferson et al. (1987) as modified by Kosugi et al. (1990). The explants were immersed for $24 \mathrm{~h}$ at

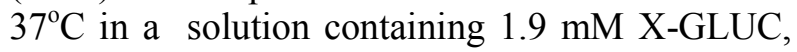
$20 \%$ methanol, $0.5 \mathrm{mM}$ potassium ferricyanide, $0.5 \mathrm{mM}$ potassium ferrocyanide, $0.1 \mathrm{M}$ sodium phosphate buffer (pH 8.0).

\section{RESULTS AND DISCUSSION}

Particle bombardment offers several advantages over Agrobacterium-mediated transformation such as simplified plasmid construction and less demanding transformation protocols, since complex bacterial/plant interrelationships are eliminated (Gray and Finer, 1993). In citrus, particle bombardment was only used to transform tangelo (C. reticulata $\times$ C. paradisi) embryogenic cells. Although fifteen transgenic embryo lines 
were reported, no transgenic plants were obtained (Yao et al., 1996).

The experiments reported here demonstrate the feasibility of using microprojectile bombardment for transformation of citrus thin epicotyl explants, which can be efficiently used for regeneration of entire plants (Bespalhok et al., 2001).

Several reports indicated that incubation of target explants on culture medium before bombardment allowed the cells to be more receptive to transformation (Seki et al., 1991). Therefore, in preliminary experiments we tested different times of pre-culture of the explants before bombardment. Blue spots were only observed on explants precultured for at least three days and one week old explants showed the highest number of blue spots (data not shown). The majority of blue spots were observed on callus developed from the cambium region (Figure 1). This is the same region where adventitious buds are formed on epicotyl explants of citrus (Ghorbel et al., 1999, Bespalhok et al., 2001).

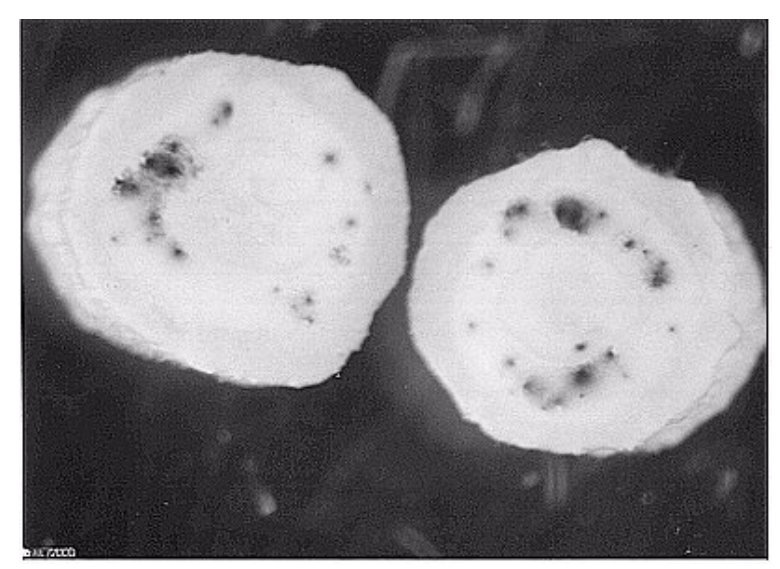

Figure 1 - Transient gene expression of uidA gene (GUS) in thin epicotyl sections of Carrizo citrange.

Regarding bombardment physical parameters, which might affect transient expression, a 1550 psi rupture disk pressure resulted in higher number of blue spots compared with 1100 psi disk (Figure 2). The distance between stopping screen and plant tissue also influenced the number of blue spots. Sixty $\mathrm{mm}$ microprojectile flying distance showed more spots compared to $90 \mathrm{~mm}$, especially with 1100 psi rupture disks (Figure 2). Therefore, 1550 psi rupture disk pressure and $60 \mathrm{~mm}$ microprojectile flying distance were used for further experiments.

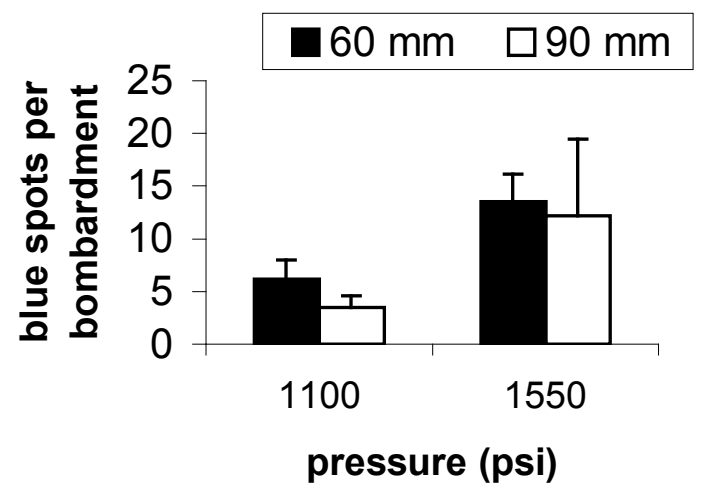

Figure 2 - Effect of rupture disk pressure and microprojectile flying distance on GUS transient expression in thin epicotyl sections of Carrizo citrange. Mean of 2 separate experiments with 3 replicates per experiment and 20 sections per replicate. Bars represent standard error.

Another physical parameter tested was the type of particle. Tungsten particles (M-17 and M-25) resulted in more blue spots than gold particles (Figure 3). The use of gold particles generally improves the transient GUS expression (Russell et al., 1992). The poor results with gold in our experiments could be due to the large range of the gold particles diameter $(1.5-3.0 \mu \mathrm{m})$ used that could have caused large physical trauma on bombarded epicotyls.

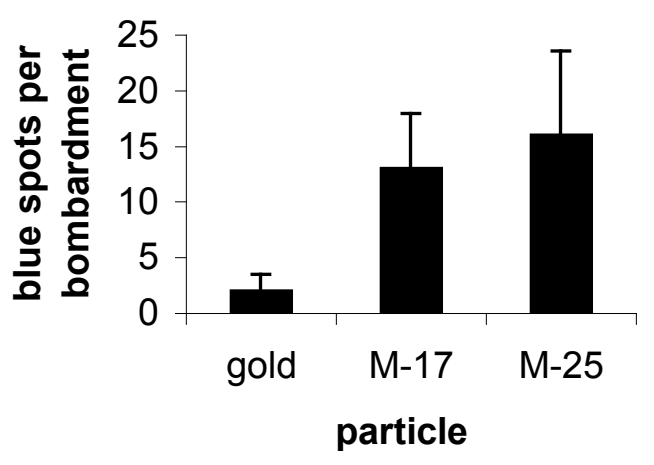

Figure 3 - Effect of particle type on GUS transient expression in thin epicotyl sections of Carrizo citrange. Mean of 3 replicates with 20 sections per replicate. Bars represent standard error.

Increasing osmoticum concentration may work by protecting the cell against leakage and bursting (lower turgor pressure) and may also improve 
particle penetration itself (Sanford et al., 1993). Pre- and post-treatment of thin epicotyl explants with osmoticum (0.2 M mannitol $+0.2 \mathrm{M}$ sorbitol) doubled the number of GUS spots (Figure 4). Enhancement of transient expression by preconditioning on high osmotic medium was also observed in other species such as rice (Nandadeva et al., 1999), wheat (Altpeter et al., 1996) and tangelo (Yao et al., 1995). In some cases, a corresponding increase in the efficiency of the stable transformation were shown (Yao et al., 1995), while in others the transient expression was not directly correlated with stable transformation events (Nandadeva et al., 1999; Altpeter et al., 1996). In any case, it could be advisable that conditions which most favoured transient expression should be used as a basic protocol for recovering stable transformants (Sanford et al., 1993)

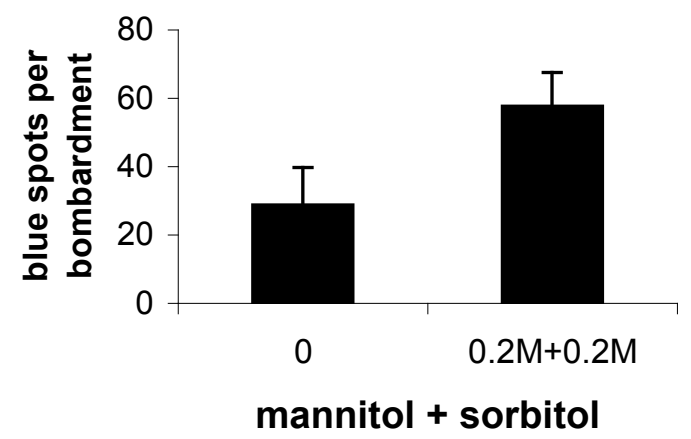

Figure 4 - Effect of osmoticum treatment on GUS transient expression in thin epicotyl sections of Carrizo citrange. Mean of 3 replicates and 20 sections per replicate. Bars represent standard error.

The best conditions for transient GUS expression in thin epicotyl section of Carrizo citrange were: 7 days pre-culture of explants, M-25 tungsten particles, 1550 psi helium pressure, $60 \mathrm{~mm}$ microprojectile flying distance, and pre- and postculture of explants on high osmoticum medium (0.2 M mannitol $+0.2 \mathrm{M}$ sorbitol) $4 \mathrm{~h}$ prior and $20 \mathrm{~h}$ after bombardment, respectively. Under these conditions, the frequency of bombarded explants with blue spots was $93 \%$ and a mean of 102 spots per bombardment (20 explants/plate) was achieved (Figure 5).

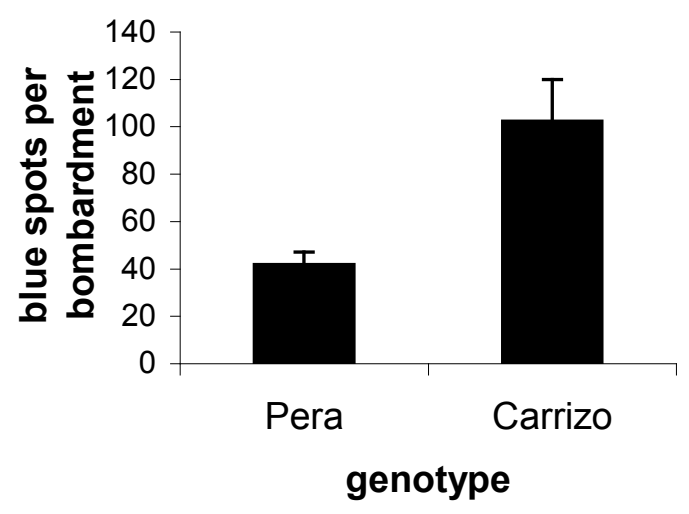

Figure 5 - Effect of genotype on GUS transient expression in thin epicotyl sections. Mean of 2 experiments with 5 replicates per experiment and 20 sections per replicate. Bars represent standard error.

When sweet orange cv. Pera was bombarded with the same conditions cited above a lower number of spots were observed compared to Carrizo (Figure 5 ). The bombardment of epicotyl thin explants is currently being used in our laboratory for stable transformation of Carrizo citrange and sweet orange.

\section{ACKNOWLEDGMENTS}

We gratefully acknowledge the receipt of pE2113GUS from Y. Ohashi, National Institute of Agrobiological Resources, Japan. Also, the authors thank to Ms. S. A. Kudo for her excellent technical assistance. J. C. Bespalhok F. and A. K. Kobayashi were supported by a RHAE/CNPq fellowship. This research was partially financed by Fundação Araucária.

\section{RESUMO}

Nosso objetivo é desenvolver um protocolo para transformação genética de Citrus através do bombardeamento de partículas usando cortes finos de epicótilo como explantes alvo. Neste trabalho foram otimizadas condições para a expressão transiente usando citrange carrizo (Citrus sinensis $x$ Poncirus trifoliata) como modelo. Epicótilos de plântulas de citrange carrizo germinadas in vitro foram cortadas transversalmente em seções de 1 $\mathrm{mm}$ e cultivadas em meio MS com $5 \mu \mathrm{M}$ no escuro. Depois de uma semana, explantes foram 
bombardeados com o plasmídio pE2113-GUS usando um aparelho de alta pressão de hélio (PDS 1000/He Bio-Rad). As melhores condições para a expressão transiente foram: partículas de tungstênio M-25, pressão de hélio de 1550 psi, distância de $9 \mathrm{~cm}$ entre os explantes e DNA/particle holder e cultivo dos explantes em meio com alta osmolaridade $(0,2 \mathrm{M}$ manitol $+0,2$ $\mathrm{M}$ sorbitol) $4 \mathrm{~h}$ antes e $20 \mathrm{~h}$ depois do bombardeamento. Usando estes parâmetros, uma média de 102 pontos azuis por bombardeamento (20 explantes/placa) foi obtida. Este protocolo esta sendo usado atualmente para transformação de citrange Carrizo e adaptado para transformação de laranja doce (Citrus sinensis).

\section{REFERENCES}

Altpeter, F.; Vasil, V.; Srivastava, V.; Stöger, E. and Vasil, I. K. (1996), Accelerated production of transgenic wheat (Triticum aestivum L.) plants. Plant Cell Rep., 1612-17.

Bespalhok F. J. C.; Kobayashi, A. K.; Pereira, L. F. P.; Hissano, Z. and Vieira, L.G.E. (2001), In vitro adventitious shoot regeneration from sweet orange (Citrus sinensis) using thin epicotyl sections. Crop Breed. Appl. Biotech., 1, 27-34.

Bond, J. E. and Roose, M. L. (1998), Agrobacteriummediated transformation of the commercially important citrus cultivar Washington navel orange. Plant Cell Rep., 18, 229-234.

Ghorbel, R.; Juárez, J.; Navarro, L. and Peña, L. (1999), Green fluorescent protein as a screenable marker to increase the efficiency of generating transgenic woody fruit plants. Theor. Appl. Genet., 99, 350-358.

Gmitter Jr., F. G.; Grosser, J. W. and Moore, G. A. (1992), Citrus. In: Hammerschlag, F. A. and Litz, R.E. (ed.). Biotechnology of perennial fruit crops. Cambridge : CAB International. pp. 335-369.

Gray, D. J. and Finer, J. J. (1993), Development and operation of five particle guns for introduction of DNA into plant cells. Plant Cell Tiss. Org. Cult., 33, 219.

Gutiérrez-E, M. A.; Luth, D. and Moore, G. A. (1997), Factors affecting Agrobacterium-mediated transformation in Citrus and production of sour orange (Citrus aurantium L.) plants expressing the coat protein gene of citrus tristeza virus. Plant Cell Rep., 16745-753.

Jefferson, R. A. (1987), Assaying chimeric genes in plants: the GUS gene fusion system. Plant Mol. Biol. Rep., 5, 387-405.
Kaneyoshi, J.; Kobayashi, S.; Nakamura, Y.; Shigemoto, N. and Doi, Y. (1994), A simple and efficient gene transfer system of trifoliate orange (Poncirus trifoliata Raf.). Plant Cell Rep., 13, 541-545.

Kosugi, S.; Ohashi, Y.; Nakajima, K. and Akai, Y. (1990), An improved assay for $\beta$-glucuronidase in transformed cells: methanol almost completely suppresses a putative endogenous $\beta$-glucuronidase activity. Plant Sci., 70133-140.

Luth, D. and Moore, G. (1999), Transgenic grapefruit plants obtained by Agrobacterium tumefaciensmediated transformation. Plant Cell Rep., 57, 219-222.

Mitsuhara, I.; Ugaki, M.; Hirochika, H.; Oshima, M.; Murakami, T.; Gotoh, Y.; Katayose, Y.; Nakamura, S.; Honkura, R.; Nishimiya, S.; Ueno, K.; Mochizuki, A.; Tanimoto, H.; Tsugawa, H.; Otsuki, Y. and Ohashi, Y. (1996), Efficient promoter cassettes for enhanced expression of foreign genes in dicotyledonous and monocotyledous plants. Plant Cell Physiol., 37, 49-59.

Moore, G. A.; Jacono, C. C.; Neidigh, J. L.; Lawrence, S. D. and Cline, K. (1992), Agrobacterium-mediated transformation of Citrus stem segments and regeneration of transgenic plants. Plant Cell Rep., 11, 238-242.

Murashige, T. and Skoog, F. (1962), A revised medium for rapid growth and bioassays with tobacco tissue cultures. Physiol. Plant., 15473-479.

Nandadeva, Y. L.; Lupi, C. G.; Meyer, C. S.; Devi, P. S.; Potrykus, I. and Bilang, R. (1999) Microprojectile-mediated transient and integrative transformation of rice embryogenic suspension cells: effects of osmotic cell conditioning and of the physical configuration of plasmid DNA. Plant Cell Rep., 18500-504.

Peña, L.; Cervera, M.; Juárez, J.; Navarro, A.; Pina, J. A. and Durán-Vila, N. (1995a), Agrobacteriummediated transformation of sweet orange and regeneration of transgenic plants. Plant Cell Rep., 14, 616-619.

Peña, L.; Cervera, M.; Juárez, J.; Ortega, C.; Pina, J. A.; Durán-Vila, N. and Navarro, L. (1995b), High efficiency Agrobacterium-mediated transformation and regeneration of citrus. Plant Sci., 104, 183-191.

Peña, L.; Cervera, M.; Juárez, J.; Navarro, A.; Pina, J. A. and Navarro, L. (1997), Genetic transformation of lime (Citrus aurantifolia Swing.): factors affecting transformation and regeneration. Plant Cell Rep., 16, 731-737.

Peña, L. and Navarro, L. (1999), Transgenic citrus. In: Bajaj, Y.P.S. (ed.). Transgenic trees. SpringerVerlag, Berlin. pp. 39-54.

Russell, J. A.; Roy, M. K. and Sanford, J. C. (1992), Physical trauma and tungsten toxicity reduce the efficiency of biolistc transformation. Plant Physiol., 98, 1050-1056. 
Sanford, J. C.; Smith, F. D. and Russel, J. A. (1993), Optimizing the biolistc process for different biological applications. Meth. Enzymol., 217, 483-509.

Seki, M.; Komeda, Y.; Iida, A.; Yamada, Y. and Morikawa, H. (1991), Transient expression of betaglucuronidase in Arabidopsis-thaliana leaves and roots and Brassica-napus stems using a pneumatic particle gun. Plant Mol. Biol., 17259-263.

Vardi, A.; Bleichman, S. and Aviv, D. (1990), Genetic transformation of Citrus protoplasts and regeneration of transgenic plants. Plant Sci., 69, 199-206.

Yao, J. L.; Wu, J. H.; Gleave, A. P. and Morris, B. A. M. (1996), Transformation of citrus embryogenic cells using particle bombardment of transgenic embryos. Plant Sci., 113, 175-183. 